\title{
Captura, ejecución, decapitación: reflexiones sobre guerra y poder en el antiguo Egipto durante los períodos Predinástico y Dinástico Temprano*
}

\author{
Augusto Gayubas \\ Universidad de Buenos Aires / CONICET, Argentina
}

Fecha de recepción: 14 de mayo de 2020. Fecha de aceptación: 1 de junio de 2020.

\begin{abstract}
Resumen
Indicadores arqueológicos, iconográficos y, en alguna medida, epigráficos ofrecen información sobre prácticas bélicas en el valle del Nilo de los períodos Predinástico y Dinástico Temprano, así como vestigios de la captura y potencial ejecución de prisioneros y determinadas mutilaciones, principalmente decapitaciones. Un análisis centrado en la relación entre tales prácticas y el ámbito de lo sociopolítico, atento a la delimitación entre escenarios no estatales y estatales, permitirá reflexionar sobre las particularidades del ejercicio de la violencia en las distintas fases que conforman dicho arco cronológico.
\end{abstract}

Palabras clave: guerra, violencia, poder, Egipto Predinástico/Dinástico Temprano

Capture, Execution, Decapitation: Reflections on War and Power in Ancient Egypt during the Predynastic and Early Dynastic Periods

\footnotetext{
Abstract

Archaeological, iconographic and, to some extent, epigraphic evidence provide information on warlike activities in Predynastic and Early Dynastic Egypt. They also offer traces of the capture and potential execution of

* El presente trabajo amplía enunciados comunicados en las I Jornadas de Investigación del Instituto de Historia Antigua Oriental, celebradas en dicho instituto de la Facultad de Filosofía y Letras de la Universidad de Buenos Aires los días 13 y 14 de mayo de 2019. Cumpliéndose aquel año un decenio del fallecimiento de Eugenia A. de Borgogno, bibliotecaria del instituto cuando yo transitaba mis primeros años de formación en historia antigua, evoqué su memoria en mi exposición y hago lo propio en esta humilde nota al pie.
} 
prisoners, as well as of mutilations - primarily beheadings. An analysis focused on the relationship between such violent images and/or practices and the sociopolitical sphere will allow us to consider the use of violence in different phases of Early Egypt, and the way it is connected to non-State and State scenarios.

Keywords: warfare, violence, power, Predynastic/Early Dynastic Egypt

Hace casi sesenta años, Abraham Rosenvasser, fundador del Instituto de Historia Antigua Oriental de la Facultad de Filosofía y Letras de la Universidad de Buenos Aires y creador de RIHAO, publicó un artículo en la revista Humanidades de la Universidad Nacional de La Plata en el que ensayaba una serie de consideraciones sobre el motivo iconográfico del sometimiento del enemigo, tan habitual en las manifestaciones visuales de la realeza egipcia a lo largo de la historia faraónica. El desencadenante del artículo fue el hallazgo, en el marco de la misión arqueológica franco-argentina en Sudán que participó de las tareas de rescate y estudio derivadas de la construcción de la presa alta de Asuán, de un relieve que formaba parte del templo de Ramsés II en Aksha y que presentaba una variante del mencionado motivo (Rosenvasser, 1961; Vercoutter, 1962).

A pesar del paso de las décadas, tres observaciones del investigador relativas no puntualmente a la evidencia de Aksha sino al motivo del sometimiento del enemigo en general merecen nuestra atención. La primera de ellas apunta que, si bien la acción insinuada en dicho motivo evoca una potencial ejecución o, en términos de Rosenvasser, un "ritual del sacrificio", el mensaje subyacente parece ser la exaltación del "poder combatiente del faraón" (Rosenvasser, 1961: 107), evidente en el armamento empleado y/o portado -en Aksha, como en otras imágenes, el rey sostiene más de un arma (Hall, 1986) - y en las inscripciones jeroglíficas que acompañan a algunos de tales ejemplares -que conectan tal motivo con el resultado (real, potencial o imaginado) de episodios bélicos.

La segunda observación de interés es aquella que plantea la presumible existencia de antecedentes predinásticos ("en época prehistórica", escribe el investigador) para una práctica compatible con las escenas de ejecución del enemigo, algo que, como se ha sugerido y veremos a continuación, puede inferirse en algunos indicadores iconográficos $-y$ tal vez arqueológicos- del valle del Nilo (Köhler, 2002).

Por último, Rosenvasser pone un especial cuidado en justificar su rechazo a las hipótesis que negaban la posibilidad práctica del sacrificio o la ejecución del enemigo en el Egipto faraónico por considerar las imágenes alusivas como simulacros sustitutivos que hallarían su razón de ser en una supuesta "aversión a la crueldad" inherente a la población egipcia. Sin restarle valor simbólico, el investigador interpreta la imagen como la expresión de un tipo de práctica ejecutada o conmemorada, o incluso -podríamos añadir- como síntesis, en una acción o en un motivo iconográfico, de un conjunto de prácticas (por ejemplo, una victoria militar condensada prácticamente en un ritual de ejecución y/o 
iconográficamente en la escena del sometimiento del enemigo). ${ }^{1}$ Esto no implicaría otra cosa que reconocer que tal práctica debió formar parte de los usos posibles, y en ocasiones reales, del poder coercitivo del rey, y podemos de ello colegir que la existencia de indicadores preestatales puede apuntar al ejercicio de una violencia no estatal, esto es, no asociada a la concentración permanente de la fuerza por un grupo sino a la exaltación de los atributos guerreros por parte de líderes de todos modos vinculados con la práctica bélica.

Lo que sigue son algunas reflexiones sobre la relación entre violencia bélica y poder en el valle del Nilo durante los períodos Predinástico y Dinástico Temprano (ca. 4500-2700 a.n.e.), en contextos tanto no estatales como estatales, en torno a la evidencia de actividades militares y a las imágenes y presuntas prácticas que debieron involucrar no sólo la captura y la ejecución (o su amenaza) de enemigos, sino también (en fases específicamente estatales) otra forma de agresión sobre el cuerpo humano como fue la mutilación, más concretamente la decapitación.

\section{Guerra}

¿Qué podemos decir de la práctica bélica, entendida como contexto o presupuesto práctico para los actos e imágenes de captura, ejecución o mutilación, en las fases tempranas del antiguo Egipto? La evidencia que apenas esbozaremos proviene de distintos puntos del valle y el delta del Nilo o inmediatos alrededores y corresponde a un arco cronológico que abarca los períodos Neolítico (ca. 5500-4500 a.n.e.), Predinástico (incluyendo el período Badariense y las fases Nagada I-IIIb, ca. 4500-3050 a.n.e.) y Dinástico Temprano (dinastías I-II, ca. 3050-2700 a.n.e.).

Muy resumidamente, podemos diferenciar, por un lado, la evidencia arqueológica, y por el otro, la evidencia iconográfica y -en menor medida, y principalmente acompañando a la anterior- epigráfica (Ferguson, 1997). Respecto a lo primero, las armas son el indicador más frecuente (Wolf, 1926: 4-19; Shaw, 1991: 31-44; 2019, 94-96, 100-101; Gilbert, 2004: 33-72; Herold, 2009: 193-195). Entre aquellas que pudieron ser utilizadas en la actividad bélica (sea que fueran específicamente construidas para tal fin o que tuvieran otras funciones alternativas) se cuentan algunos tipos de puntas de flecha y de lanza mayormente de sílex y cabezas de hacha de piedra y sílex que se documentan desde el período Paleolítico en adelante, incorporándose las cabezas de hacha de cobre hacia fines de Nagada I y Nagada II, con mayor presencia a partir de Nagada IIIab.

1 También al considerar las estatuillas de cautivos y textos de execración del Reino Antiguo, Rosenvasser (1961: 114) deduce su valor mágico no de una dimensión sustitutiva sino de su carácter -siquiera potencial- de "prefiguración del acto" de violencia y de su correspondencia con el "cumplimiento efectivo en la vida del rey" (1961: 110) de los actos de guerra, captura y/o ejecución de prisioneros que pudieron, según se podría aventurar, ser revestidos de un aura de eternidad al manifestarse en materialidades cultuales o funerarias. Entre los autores con los que discutía en torno a estos puntos estaba, por ejemplo, Jean Capart (1940). 
Las cabezas de maza de piedra, cuya función debió haber sido específicamente militar (asociada al combate cuerpo a cuerpo y/o a la ejecución), aparecen en el registro arqueológico a partir del período Neolítico, contemporáneamente a los primeros indicios de cuchillos de sílex (las hojas de cuchillos de cobre se datan a partir de Nagada IIcd), mientras que los estilos discoidal y piriforme de las mazas aparecerán en las fases Nagada I y Nagada II, respectivamente (Ciałowicz, 1987; Gilbert, 2004: 35-41).

Acaso por haber sido un arma concretamente orientada a la guerra y/o a la ejecución, las mazas parecen haber adquirido a la vez un valor simbólico como insignia de prestigio o liderazgo durante el período Predinástico, quizás evocando los atributos de fuerza implícitos en su utilidad práctica y, por lo tanto, asociados a roles sociales considerados relevantes (su colocación en tumbas o recintos cultuales sugiere, en efecto, cierta evocación ritual del implemento -arma o modelo de arma- y, por extensión, de la relación entre un individuo o grupo y la actividad bélica o el ejercicio real o potencial de la violencia).

Otro indicador arqueológico lo constituyen los criterios defensivos de habitación (Gayubas, 2018). Por un lado, la disposición de áreas de residencia del período Neolítico y comienzos del Predinástico en terreno ligeramente elevado a lo largo del borde del desierto sugiere unas pautas defensivas de asentamiento (Hoffman, 1979: 148; Gilbert, 2004: 100). A ello se suman vestigios de estructuras defensivas algo posteriores. Concretamente, un muro de dos metros de espesor de la fase Nagada II al norte del complejo residencial de South Town en Nagada, sur de Egipto, cuyo propósito para la protección o disuasión ante la potencial agresión de grupos humanos no puede ser asegurada pero tampoco descartada (Campagno, 2004: 690), y más evidentes fortificaciones en Tel esSakan, en el sur de Palestina, de Nagada IIIab y comienzos de la Dinastía I, y en Elefantina, en el límite meridional con la Baja Nubia, de la Dinastía I, posteriormente devenida ciudad fortificada hacia la Dinastía III (Vogel, 2009: 168170; Moeller, 2016: 76-81). Aún más al sur, en torno a la segunda catarata, se ha documentado la presencia del Estado egipcio hacia la Dinastía II en Buhen, sin que pueda afirmarse con seguridad que ello implicara la construcción de una estructura defensiva como la que tendría lugar a partir de la Dinastía IV (Wilkinson, 1999: 180-181; Török, 2009: 55). ${ }^{2}$

Un tercer indicador corresponde a los indicios del abandono repentino de sitios y regiones que puede interpretarse como debido a alguna clase de agresión $\mathrm{u}$ hostigamiento sobre la población: el abandono del sitio de Maadi, en el vértice del delta, hacia Nagada IIc (Rizkana y Seeher, 1987: 78; Tutundžić, 1989: 429; Campagno, 2002: 191); el reemplazo drástico de la cultura material del norte por aquella del sur en Tell el-Farkha y Tell el-Iswid, en el delta oriental, hacia fines de Nagada II y comienzos de Nagada III (Campagno, 2002: 188-189; Ciałowicz, 2011:55-57; Guyot, 2015: 15); ${ }^{3}$ y, algo más tarde, durante la Dinastía

2 Sobre el asentamiento del Reino Antiguo, véase O'Connor (2014), quien rechaza, sin embargo, la idea de una presencia egipcia durante la Dinastía II.

3 A ello se añaden los indicios de destrucción por fuego de un recinto presumiblemente administrativo en Tell el-Farkha, hacia fines de Nagada Illa (Ciałowicz, 2011: 56-57). 
I, la destrucción e interrupción en el uso del cementerio real de Qustul, en la Baja Nubia, y la relativa desaparición del Grupo A del registro material de la región (Williams, 1986: 183; Török, 2009: 53-55).

El último indicador arqueológico que podemos tomar en consideración aquí corresponde a los restos humanos. Aquellos que más elocuentemente indican la recepción de violencia física pertenecen a fines del período Paleolítico, tratándose de un individuo adulto de 20.000 años de antigüedad con dos puntas de proyectiles de piedra en la zona del abdomen hallado en Wadi Kubbaniya, en el sur de Egipto (Wendorf y Schild, 1986; Midant-Reynes, 2000 [1992]: 65), y el cementerio 117 de Jebel Sahaba, en el valle del Nilo sudanés, datado hacia 12.000-10.000 a.n.e. y consistente en 59 cadáveres de los cuales casi la mitad presentaba puntas de proyectiles de piedra dispuestas junto a los cuerpos (indicio de que debieron estar clavadas en el tejido blando) e incluso en algunos casos incrustadas en huesos, en simultáneo con lesiones en cráneos y otras extremidades, incluyendo los antebrazos (Wendorf, 1968; Hoffman, 1979: 90-99). De los períodos Neolítico, Predinástico y Dinástico Temprano perduran los datos de unos pocos testimonios de heridas craneales y en antebrazos compatibles con el impacto de armas que pudieron ser utilizadas en situaciones de conflicto intergrupal en el valle del Nilo, incluida la Baja Nubia (Rampersad, 1999: 199-201; Gilbert, 2004: 73-80). Tal circunstancia no debería llevar a confusión respecto a la frecuencia de situaciones de conflicto violento. La cantidad de información osteológica que se perdió no sólo a raíz del paso del tiempo sino también de los precarios relevamientos conducidos en los orígenes de la disciplina arqueológica en Egipto es inconmensurable (Gilbert, 2004: 79-80; Shaw, 2019: 86). Ello hace particularmente llamativo que, en algunos sitios predinásticos en los que se ha excavado recientemente con los debidos cuidados de manipulación, registro y análisis, los resultados documenten lesiones que ofrecen pistas sobre prácticas presumiblemente violentas. Tal es el caso de las heridas craneales o en vértebras cervicales del cementerio HK43 de Hieracómpolis (Nagada IIbc) (Maish, 1999; Droux, 2007; Dougherty y Friedman, 2008). Como advierten Potter y Powell (2003: 26) en relación con las primeras, "considerando que la mayor parte de los cráneos han desaparecido, están pobremente preservados o son extremadamente fragmentarios, resultó notable haber encontrado seis casos de lesión con elemento contundente en la cabeza, y un caso donde esto sucedió dos veces", lo cual condujo a los autores a concluir que Hieracómpolis durante el período Predinástico "no era siempre un lugar pacífico".

La evidencia iconográfica y -aunque minoritariamente- epigráfica, es menos directa pero, leída en simultáneo con los indicios previamente considerados, conforma un corpus de utilidad para inferir prácticas de tipo bélico (Campagno y Gayubas, 2015). Los testimonios de esta clase consisten principalmente en imágenes alusivas al ejercicio de la violencia o al sometimiento, incluyendo enfrentamientos armados -como los contenidos en la decoración mural de la tumba 100 de Hieracómpolis (Quibell y Green, 1902: pls. LXXV-LXXVIII) o en el mango de cuchillo de Dyebel el-Arak (Musée du Louvre E11517; Bénédite, 1916), ambos de Nagada IIcd-y personajes derrotados o prisioneros -como en la paleta del Campo de Batalla de Nagada IIIb (British Museum EA20791; Ashmolean Museum AN1892.1171; Midant-Reynes, 2000 [1992]: 242-243 y fig. 20) o en la base de dos estatuas del rey Jasejem de la Dinastía II (Quibell, 
1900: pls. XXXIX-XLI). Pero también aluden a fortificaciones o al asalto a recintos fortificados -como en algunas paletas de Nagada IIIab y en etiquetas de la Dinastía I (Gayubas, 2018: 36-37). A ello se suman referencias escritas a acciones militares durante algunos años de reinado de la Dinastía I en los anales contenidos en la Piedra de Palermo y fragmentos asociados de la Dinastía V (Wilkinson, 2000).

Algunos de estos testimonios los retomaremos en el próximo apartado, pero merece la pena indicar aquí que se trata de escenas de las cuales tenemos constancia desde fines de la fase Nagada I, como se ve en una serie de motivos en vasos cerámicos (dos hallados en tumbas del cementerio $U$ de Abidos, otros dos de proveniencia desconocida) que presentan a unos personajes destacados por su atuendo y tamaño en una relación de presumible violencia, mediada por un arma o por un lazo, con otros personajes de menor tamaño (Gayubas, 2015: 47; véase más abajo). Estos vasos son más o menos contemporáneos de un modelo en arcilla de una muralla presumiblemente defensiva hallada en Abadiya, en el sur de Egipto (Ashmolean Museum E3202; Vogel, 2009: 167 y Abb. 3). Quizás coetáneo o más temprano, aunque más remoto espacialmente, un grabado rupestre de la "Caverna de las Bestias" (VI-IV milenios a.n.e.) en Gilf Kebir, en el desierto occidental, representa a un individuo empuñando lo que parece ser un arma (posiblemente un hacha o una maza) frente a un individuo en posición invertida que podría simbolizar a un personaje derrotado o muerto, acompañados de dos hileras de individuos aparentemente enfrentados con los brazos levantados, quizás emulando un combate o el resultado de un enfrentamiento saldado con un grupo victorioso y otro derrotado (Bárta y Frouz, 2010: 35-40; Campagno, 2016: 18). ${ }^{4}$

De aquello que acabamos de enumerar, algunos indicios están más presentes o mejor representados en unas áreas o períodos que en otros, pero considerados en conjunto ofrecen una imagen lo suficientemente sugestiva: la de un horizonte de conflictos intergrupales que pudieron producirse con distintos niveles de frecuencia o regularidad pero que, cualesquiera fueran sus motivaciones y resultados, subrayan la presencia general del fenómeno bélico en el valle del Nilo a lo largo de las fases consideradas.

\section{Captura y ejecución}

¿Existen testimonios de los períodos que nos ocupan que nos informen sobre prácticas de captura y ejecución de enemigos? Como ya anticipamos, algunos de los indicios iconográficos de guerra o de lo que pudo constituir el resultado de actividades militares atañen precisamente a esta cuestión.

4 A pesar de la lejanía espacial, resulta pertinente tomar en consideración este testimonio dados los indicios existentes de interacciones socioculturales y movimientos poblacionales entre el Sahara oriental y el valle del Nilo, especialmente a partir del VI milenio a.ก.e. 
La captura de prisioneros (sin señales de presumible ejecución o de la amenaza de tal acción) queda atestiguada iconográficamente hacia Nagada Ic en los motivos de dos vasos cerámicos de proveniencia desconocida (Petrie Museum UC15339; Musée du Cinquantenaire E3002) que presentan a un personaje destacado por su tamaño y atuendo sosteniendo, mediante lo que parece ser un lazo, a uno o más personajes de menor tamaño (Petrie, 1920: pl. XVIII.74; Scharff, 1928: 268-269 y pl. XXVIII). También en un vaso de la tumba U-415 del cementerio $U$ de Abidos, que parece representar a una hilera de tales individuos sostenidos con lazos de sus cuellos (Dreyer et al., 2003: 83 y Taf. 15.b), y en una estatuilla de datación dudosa, pero posiblemente correspondiente a esta época, de un individuo que pareciera tener los brazos atados a la espalda (Schäfer, 1896: 160).

En las fases siguientes aparecen representados prisioneros individuales o dispuestos en hileras, atados mediante sogas de los brazos o el cuello, en objetos como el mango de cuchillo de la tumba U-127 de Abidos de Nagada IId (Dreyer, Hartung y Punpenmeier, 1993: 26-27), el incensario de la tumba L24 de Qustul de Nagada IIIb (Oriental Institute Museum E24069; Williams, 1986: 138-145 y pls. 34, 38), una cabeza de maza de marfil hallada en Hieracómpolis de Nagada IIIb-Dinastía I (Quibell, 1900: 7 y pl. XII.4) y la Paleta del Campo de Batalla de Nagada IIIb (la cual contiene también personajes derrotados siendo devorados por buitres, uno de ellos con los brazos atados a la espalda; Midant-Reynes, 2000 [1992]: 242-243 y fig. 20), así como en las inscripciones rupestres de Dyebel Sheikh Suleiman en la Baja Nubia y, quizás, de Nag el-Hamdulab en la zona de Asuán, de Nagada IIIb (Wilkinson, 1999: 177-179; Hendrickx, Darnell y Gatto, 2012: 1074 y fig. 7; Bestock, 2018: 62-64). ${ }^{5}$ También se representa a prisioneros en objetos de la Dinastía I como la Cabeza de Maza de Narmer (Ashmolean Museum E3631; Quibell, 1900: pl. XXVI.b), una caña de marfil del reinado de Qaa (Petrie, 1900: pls. XII.12-13 y XVII.30), otros objetos de marfil (British Museum EA35514; Petrie, 1901: pls. III.2, IV.12, IV.20; Capart, 1905: fig. 190; Vandier, 1952: figs. 558 y 561) y una serie de pequeñas estatuillas, algunas posiblemente más tempranas (Gilbert, 2004: fig. 8.21; Wengrow, 2007 [2006]: 223; De Wit, 2008: passim), y quizás en la base de una estatua del rey Jasejem de la Dinastía II (Quibell, 1900: pl. XL).

Respecto a las ejecuciones, dos vasos cerámicos de Nagada Ic hallados en el cementerio U de Abidos, en las tumbas U-239 y U-415, presentan escenas que se asemejan a lo que tiempo después sería el motivo del sometimiento del enemigo, con un personaje en mayor tamaño y con un atuendo distintivo sujetando al parecer mediante lazos a unos personajes de menor tamaño, y asiendo, a un mismo tiempo, un objeto que podría ser una maza, acaso disponiéndose a golpear a los otros, que podrían ser prisioneros (Dreyer et al., 1998: 113-114 y Taf. 6.d-f; 2003: 81 y Taf. 15.a). Otro presunto antecedente del motivo del sometimiento del enemigo es el que contiene la pintura mural de la tumba 100 de Hieracómpolis (Nagada IIc), en la que tres personajes aparentemente "postrados y atados" (Cervelló Autuori, 2009: 74) son amenazados

5 Algunos autores han propuesto datar una de las inscripciones de Dyebel Sheikh Suleiman hacia la Dinastía I (Somaglino y Tallet, 2014). 
por otro personaje de mayor tamaño que sostiene en alto lo que podría ser un arma (Quibell y Green, 1902: pls. LXXV-LXXVIII). Una variación la presenta el mango de cuchillo de Dyebel el-Arak (Nagada IIcd), el cual además de representar a personajes derrotados, posiblemente muertos, y enfrentamientos armados, incluye una pareja de individuos (esta vez del mismo tamaño) en la cual uno conduce y amenaza con una maza a otro que es sujetado con los brazos atados a la espalda (Bénédite, 1916).

Prisioneros (arrodillados o de pie) con sus brazos atados a la espalda y un personaje armado en señal de amenaza aparecen en la inscripción rupestre de Dyebel Chauti (desierto occidental) de Nagada IId-IIIa (Darnell, 2002: pls. 9-11), en el mango de cuchillo del depósito principal de Hieracómpolis de Nagada IIdNagada IIIab (Ashmolean Museum E4975; Raffaele, 2010: fig. 2.3), en un mango cilíndrico de marfil de Narmer de Hieracómpolis (Ashmolean Museum E3915, donde quien blande el arma es el pez siluro que da nombre al rey, de modo similar a una etiqueta de marfil del mismo reinado en la que el prisionero no parece tener los brazos atados; Wengrow, 2007 [2006]: fig. 9.13), en diversos cilindros de marfil de la Dinastía I hallados en Hieracómpolis (Quibell, 1900: pl. XV), y en una etiqueta del reinado de Aha hallada en Abidos, en la cual es el serej del rey el que levanta la presunta maza (Petrie, 1901: pls. III.2, XI.1). Otras imágenes de sometimiento o potencial ejecución de enemigos por parte de figuras humanas o serejs se representan en la paleta de Narmer (Wengrow, 2007 [2006]: figs. 2.1-2), en etiquetas de los reinados de Uadyi y Den halladas en Abidos (British Museum EA55586; Dreyer et al., 1998: Taf. 12.a; 2003: Taf. 18.f; Gilbert, 2004: fig. 8.6), en un fragmento de paleta del reinado de Dyer hallado en Saqqara (Emery, 1961: 60), en inscripciones rupestres de los reinados de Dyer en Wadi Ameyra (Tallet y Laisney, 2012: fig. 11) y Den en Wadi el-Humur (Tallet, 2010: 98), en el Sinaí meridional, todas ellas de la Dinastía I, y en una serie de vasos decorados del reinado de Jasejem/uy que, configurando en rigor una inscripción jeroglífica, contienen una especie de maza que ha sido leída en asociación con el término "golpear" ( $h w t)$ posándose junto a un enemigo arrodillado o sentado que parece significar a un enemigo del delta del Nilo (Quibell, 1900: pl. XXXVIII).

Ahora bien, ¿quiénes son los prisioneros y los personajes que parecen estar a punto de ser ejecutados? ¿Quién es quien conduce o se dispone a ejecutar la acción? Respecto a lo primero, y sin detenernos en cada imagen en particular, podemos notar que hacia Nagada Ic-IIIb predominan figuras que nos resultan mayormente indeterminadas (aunque en general se las diferencia de los vencedores por su tamaño, pose, cabello y/o atuendo), que podrían corresponder a poblaciones del valle y el delta del Nilo o inmediatos alrededores y, por lo tanto, representar o simbolizar los presumibles conflictos entablados entre entidades políticas de dichas regiones en los períodos previos a la constitución del Estado dinástico. Ello no excluye la presencia de unos individuos de aspecto asiático durante Nagada IId y otros posiblemente asociados al ámbito nubio durante Nagada IIIb, en situación de cautividad. Hacia la Dinastía I, las escenas de potencial ejecución del enemigo se producen en su casi totalidad sobre personajes que, por características iconográficas (vestimenta, cabello, rostro), por referencias epigráficas y/o por su ubicación, parecen remitir a la Baja Nubia (reinados de Aha y Dyer), el Sinaí (reinados de Dyer y Den), el delta del Nilo 
(reinado de Narmer), el ámbito líbico (pudiendo tratarse del delta occidental, reinados de Narmer y Dyer), y quizás el sur de Palestina (reinado de Den, acaso más probablemente limitado al Sinaí). En los vasos de Jasejem/uy de la Dinastía II es el delta del Nilo el que parece ser personificado por el individuo a punto de ser ejecutado (así como el personaje que parece tener los brazos atados a la espalda en la base de una estatua del mismo reinado), de similar modo a lo representado en objetos del reinado de Narmer, si bien un fragmento con un personaje nubio derrotado permite suponer que no fue el norte la única fuente de prisioneros o víctimas en esta época (Wilkinson, 1999: 180). Por su parte, los cautivos que no parecen estar a punto de ser ejecutados durante la Dinastía I nos resultan en principio indeterminados, salvo un asiático identificado con la inscripción jeroglífica $s \underline{t} t$ y unas pocas estatuillas que podrían remitir al Sinaí o el sur de Palestina. ${ }^{6}$

En cuanto a los captores (allí donde son representados) y los potenciales ejecutores, podemos reconocer hacia Nagada Ic figuras destacadas por su tamaño y atuendo que podrían caracterizar a líderes o jefes, en un contexto en el que se ha documentado (mayormente en el registro funerario) la presencia de formas de diferenciación social en el Alto Egipto compatibles con la categoría antropológica de sociedades de jefatura. Tales líderes o jefes, que no habrían sostenido su posición como tales en la coacción sobre los integrantes de la propia comunidad sino quizás en la obtención de prestigio debida a la realización de ciertas actividades o a la ostentación de alguna condición particular, pudieron tener un rol o bien un aspecto militar, según sugiere la mencionada iconografía y el presumible valor adjudicado a las mazas como insignia de prestigio o liderazgo (Gayubas, 2016).

Hacia Nagada IIcd-IIIa, las escenas de ejecución o amenaza involucran tanto a personajes que, por su tamaño o atuendo, pueden calificarse de gobernantes o reyes (si atendemos al contexto presumiblemente estatal de la situación en el Alto Egipto de aquellas fases), como a combatientes o guardias que no parecen denotar ninguna jerarquía en lo que respecta a su tamaño y/o vestimenta. Las imágenes de Nagada IIIb que refieren a la captura de prisioneros tienen como protagonista, de un modo directo como captor o indirectamente como parte importante de la escena, al rey (en forma de animal salvaje, de emblema o de serej, e incluso en forma humana en un artefacto que podría señalar a un rey del Alto Egipto o de la Baja Nubia, como es el incensario de Qustul, y en las inscripciones rupestres de Nag el-Hamdulab, si se consideran en conjunto los grabados de distintas ubicaciones del sitio). En la Dinastía I, lo que predomina son las escenas de ejecución o sometimiento del enemigo, protagonizadas por el rey en forma humana o encarnado por su nombre (el serej o, durante el reinado de Narmer, el pez siluro que forma parte de su nombre), con un artefacto (si es que se toma como tal el grupo de tres cilindros de marfil hallado en Hieracómpolis) que repite la acción del sometimiento del enemigo por parte de

6 Lo mencionado no agota los testimonios (iconográficos, epigráficos y arqueológicos) que permiten reconocer, como sujetos de la agresión militar, a poblaciones del valle y el delta del Nilo, los desiertos circundantes, el Sinaí, el sur de Palestina, la Baja Nubia y el ámbito líbico -fuera lo que fuera que esto significara concretamente en aquellas épocas- (Campagno y Gayubas, 2015; Hamilton, 2016). 
un individuo de mayor tamaño cuyos rasgos no permiten descifrar si pretendía representar al rey o no. En la Dinastía II, la inscripción jeroglífica que coloca una maza junto a un enemigo se halla casi frente a un serej del rey, mientras que el prisionero que reposa en el pedestal de estatua del mismo reinado lo hace, en definitiva, bajo los pies del rey. ${ }^{7}$

Si estas imágenes pretendían o no figurar ejecuciones es difícil de saber. Resulta llamativo que, en todos los ejemplares conocidos, los golpes de ejecución no son representados (Davis, 1992: 40). Las escenas podrían estar transmitiendo un mensaje de sometimiento, amenaza, dominación o control en un sentido más general o cosmológico. Pero aun en este último caso, el hecho de que el mensaje (cualquiera fuera su audiencia y el significado último) recurriera a unos motivos tan explícitos lleva a suponer que el idioma de la violencia no sólo formaba parte del horizonte de sentido de las sociedades del valle del Nilo de aquellos períodos (Bestock, 2018: 264-265) sino que la eficacia de tales imágenes, $\mathrm{y}$ en particular de aquellas que aluden a la captura de prisioneros y a la disposición de un individuo armado a ejecutar a individuos desarmados, probablemente dependía del conocimiento de la existencia práctica (habitual o excepcional) de tales comportamientos, o como mínimo de su potencialidad, esto es, de la capacidad de una persona, grupo o institución para efectivizarla.

¿Puede la arqueología ofrecer alguna pista adicional respecto a esta cuestión? El hallazgo de armas compatibles con el tipo de implemento representado en algunas de las escenas previamente examinadas, especialmente las cabezas de maza de piedra que pudieron servir como armas de guerra y/o ejecución y acaso también las cabezas de hacha, se suma a los -escasos pero sugerentes- restos de cráneos con fracturas hundidas que coinciden con el daño que provocaría el impacto de tales instrumentos. De hecho, en las regiones en las que han sido recuperados cráneos con tales heridas datados en los períodos Neolítico y Predinástico, tenemos registro de la presencia de mazas (Merimda, Mostagedda, Hieracómpolis, Gebelein, Abidos, Naga ed-Dêr, el-Amrah) y de hachas (Merimda, el-Omari, Mostagedda, Hieracómpolis, Gebelein) (Gilbert, 2004: 33-41, 63-68 y apéndices 3-4). También tenemos tal clase de indicadores en los cementerios del norte de la Baja Nubia, atribuidos al Grupo A, desde al menos la fase Nagada II, esto es, en épocas de contacto con las poblaciones del Alto Egipto (Smith, 1910: 329ss; Nordström, 1972: 19; Rampersad, 1999: 199201). Ello permite señalar como verosímil la lectura que hace de tales heridas craneales, el resultado de prácticas asociadas al ámbito bélico o coercitivo, ya sea como parte de enfrentamientos, incursiones o ejecuciones.

La tentación de ver, en la carencia de indicadores claros de este tipo hacia el período Dinástico Temprano en el valle del Nilo, una sustitución iconográfica de prácticas predinásticas abandonadas en función de la "aversión a la crueldad" que los autores cuestionados por Rosenvasser asignaban a las élites del antiguo

7 La colocación de aparentes mazas junto a serejs del norte de Egipto durante la fase Nagada Illab (Wilkinson, 1999: 55-56; Raffaele, 2003: 140-141) quizás indicaría nuevamente esta asociación (política, ritual o meramente iconográfica) entre el dispositivo diseñado para la guerra y/o la ejecución, devenido insignia de liderazgo o realeza, y la figura del gobernante. 
Egipto, debe ser evitada dados los recaudos que, como señalamos más arriba, deben ser tomados a la hora de considerar la evidencia osteológica, con las dificultades de preservación, documentación y registro que ya hemos apuntado. En todo caso, sería de esperar que restos de enemigos ejecutados por el Estado egipcio durante el período Dinástico Temprano no recibieran siquiera un tratamiento funerario, precisamente por ser considerados enemigos, y acaso los procedentes de regiones periféricas no tuvieran un grupo de pertenencia en el territorio que estuviera en condiciones de reclamar la devolución del cadáver, todo lo cual atentaría contra su conservación.

Sin que se soslaye, pues, el aspecto simbólico de las imágenes del sometimiento del enemigo o similares y su presumible surgimiento como apropiación y recodificación estatal de recursos gráficos y conceptuales preexistentes, como los presentes en vasos cerámicos de Nagada Ic (asociados estos últimos a la exaltación o conmemoración de figuras de liderazgo de contextos preestatales, quizás vinculadas de un modo práctico o simbólico con el éxito militar o la coordinación de los esfuerzos colectivos en la guerra), la posibilidad de que hacia comienzos de la época dinástica se produjeran ejecuciones del tipo que parecen insinuar tales escenas no puede ser descartada.

¿Qué podemos concluir hasta aquí? Por un lado, que tenemos elementos para proponer la existencia de prácticas bélicas o conflictos intergrupales violentos a lo largo de los períodos que estamos considerando, cualesquiera fueran su frecuencia y motivaciones. Por otro lado, que la evidencia iconográfica, complementada con indicios arqueológicos y osteológicos, sugiere que a partir de la fase Nagada Ic, y con más presencia a partir de Nagada IIcd-IIIab, la captura y ejecución de prisioneros eran prácticas conocidas en el valle del Nilo.

Esta constatación resulta de interés dado que, como hemos esbozado más arriba, hacia Nagada I se testimonian en el Alto Egipto indicios (mayormente en el registro funerario) de cierta diferenciación social compatible con la categoría antropológica de "sociedades de jefatura". Tal clase de organización sociopolítica supondría el ejercicio de un tipo de guerra no expansiva (es decir, no orientada a la conquista territorial ni seguida de la dominación sostenida sobre una población) que no obstante, a diferencia quizás de los conflictos que pudieron tener lugar durante los períodos Paleolítico y Neolítico, pudo habilitar la obtención de cautivos y la captación de séquitos por parte de un jefe, según revelan paralelos etnográficos (Redmond, 1994; Carneiro, 2012). Ello tampoco excluiría las demostraciones de liderazgo o fuerza mediante ejecuciones (además de otras actividades como la coordinación de alianzas entre comunidades), o la expresión ritual de la diferencia entre entidades políticas mediante agresiones particulares que pudieran ser protagonizadas (práctica o iconográficamente) por un jefe en tanto ejecutor de las prescripciones colectivas.

8 Si bien algunos autores rechazan o eluden tal categoría para el abordaje del período Predinástico, la identificación de diferenciaciones sociales articuladas con cierto sedentarismo a partir de Nagada I en el Alto Egipto es habitualmente aceptada, incluso por tales autores, llegándose a describirla mediante términos menos asépticos como puede ser el de "formaciones sociales complejas" (Stevenson, 2016), que denota una caracterización histórica evolutiva y poco informativa. 
En lo que respecta a las fases Nagada II-IIIab y las dinastías I-II, se trata de contextos estatales (inicialmente en el Alto Egipto, luego a lo largo del valle y el delta del Nilo) que parecen haber movilizado un tipo de guerra expansiva consustancial al fundamento coercitivo del Estado, inicialmente mediante guerras de conquista que pudieron alternarse con extorsiones militares y alianzas circunstanciales y haber influido en la expansión política que parece haber conducido a la constitución del Estado dinástico. Pero también mediante expediciones o incursiones más allá de los límites territoriales establecidos según condicionamientos geográficos y logísticos hacia comienzos de la Dinastía I, y que podemos identificar en la extracción de recursos de regiones adyacentes y en el hostigamiento a sus poblaciones. En tal sentido, las escenas y prácticas de cautividad y presumible ejecución de las fases de dominación estatal, al menos allí donde tienen al rey como figura central o ejecutora y sean quienes fueran los enemigos en cada momento o imagen, no harían sino exaltar o celebrar el "poder combatiente" del rey (Rosenvasser, 1961: 107) o, expresado en otros términos, no harían sino manifestar el fundamento coercitivo y la lógica expansiva del Estado.

\section{Decapitación}

Ahora bien, la iconografía también nos ofrece información sobre prácticas de mutilación. Se trata de tres escenas registradas en objetos de Nagada IIIb y/o la Dinastía I. La más conocida se encuentra en el registro superior de una de las caras de la Paleta de Narmer. Aquí el rey asiste a la exhibición de diez cuerpos decapitados, la mayoría de ellos también castrados, que tienen los brazos ceñidos y conservan sus cabezas entre las piernas (Droux, 2005: figs. 2-3). También aparecen hileras de personajes decapitados en un sello del reinado de Den de la Dinastía I, que presenta simultáneamente al rey en lo que parece ser una escena de cacería del hipopótamo (de presumible connotación bélica o coercitiva), y en una placa de marfil de Nagada IIIb o la Dinastía I, hallada en el depósito principal de Hieracómpolis, esta vez con las cabezas situadas a los lados de los cuerpos (Droux, 2005; Müller, 2008).

Por su parte, la evidencia arqueológica - principalmente osteológica- es escasa pero significativa. Las investigaciones conducidas en el cementerio HK43 de Hieracómpolis (Nagada IIbc), en el Alto Egipto, revelaron la existencia de restos humanos con marcas de corte en vértebras cervicales que serían indicativas de prácticas de degollamiento y/o decapitación, ya sea sobre individuos vivos o sobre cuerpos muertos (Maish, 1999; Dougherty y Friedman, 2008). Dado que resulta difícil aceptar que se haya tratado de un ritual estrictamente funerario, pues tales indicios constituyen una minoría en relación con la totalidad de cuerpos enterrados conocidos en dicho cementerio (Dougherty y Friedman, 2008: 332; Hendrickx y Huyge, 2014: 251), ${ }^{9}$ su lectura a la luz de los testimonios

9 Las marcas de corte en vértebras cervicales, sean indicativas de degollamiento o de decapitación, se testimonian en 21 cadáveres del cementerio HK43, sobre un total de alrededor de 500. 
iconográficos previamente mencionados, si bien algo posteriores, habilita suponer que se trata de indicadores de ejecuciones o de mutilaciones post-mortem asociadas al resultado de un combate o de una incursión militar, o bien al ejercicio de la violencia por parte de una élite sobre población subordinada. ${ }^{10}$

La posibilidad de reconocer una práctica coercitiva sobre súbditos en Hieracómpolis halla sustento en el hecho de que el cementerio HK43 constituía el lugar de enterramiento de una población general, quizás sometida, en una fase en la que se testimonia la existencia simultánea de una élite presumiblemente estatal en la misma región, inferida por ejemplo en el cementerio HK6 (Friedman, 2011; Hierakonpolis Expedition, s/f). Un indicador que confluye con tal interpretación, aunque sin referirse específicamente a Hieracómpolis en el período Predinástico, se encuentra en una entrada de los anales reales contenidos en la Piedra de Palermo (compuesta en la Dinastía V), correspondiente a un año de reinado del rey Dyer de la Dinastía I. Ésta contiene la alusión a una práctica ritual llamada "seguir a Horus" ( $\check{m} m s ~ h r$ ) , al parecer asociada a la recolección de tributo o al recuento de recursos por parte de la realeza y que, como tal, pudo tener una dimensión coercitiva (Wilkinson, 2000: 97-98). Si bien tal tipo de referencia aparece también en otros años de reinado de diversos reyes (y en algunas etiquetas de la Dinastía I), lo significativo de esta entrada en particular es que, debajo de tal indicación, se encuentra una inscripción que se ha leído como "rejit decapitados" (Diego Espinel, 2006: 188).

Las aves-rejit (especie de avefrías) simbolizarían a la población subordinada, y por lo tanto tal declaración parece vincular la práctica de la tributación estatal con el ejercicio de la violencia (Baines, 1995: 133; Campagno, 2013: 215). Lo que interesa, en todo caso, es que el modo de representar la muerte de -o amenaza sobre- tal población sometida consiste en colocar un cuchillo sobre el cuello del ave-rejit, explicitando una asociación antigua entre la exigencia de obligaciones económicas y la práctica o la amenaza de la decapitación.

Tomando en cuenta este testimonio pero también el tipo de herida examinado en los restos humanos previamente considerados y los vestigios de armas disponibles, es razonable pensar que los instrumentos utilizados para las prácticas de

10 Similares testimonios en los cementerios oriental y occidental de Adaïma (entre Nagada Ic y el período Dinástico Temprano), a menudo interpretados como sacrificios o vinculados a la práctica del acompañamiento funerario (pues se suelen dar en el contexto de enterramientos múltiples), son más difíciles de abordar que los del cementerio HK43 debido a los inconvenientes interpretativos que ofrecen en términos de la composición social de los enterramientos, pero no permiten descartar su relación con alguna forma de ejercicio de la violencia (Ludes y Crubézy, 2005; Crubézy y Midant-Reynes, 2005), sea sobre población vencida militarmente o sobre población subordinada (piénsese, por ejemplo, que el mismo principio del acompañamiento funerario, al cual se ha querido vincular estos testimonios, supone alguna clase de dependencia o subordinación, aunque más no sea de tipo personal). Sobre esto último, véase Testart (2005). Por otro lado, en el mismo cementerio HK43, la presencia contemporánea a los testimonios de degollamiento y decapitación de cráneos con indicios de golpes de ejecución, e incluso de escalpado (Dougherty y Friedman, 2008), colabora con una lectura violenta del registro. 
degollamiento y/o decapitación que parecen vincularse con la violencia bélica o la coerción estatal fueron cuchillos (Gilbert, 2004: 70; Ludes y Crubézy, 2005: 91; Dougherty y Friedman, 2008: 316), implemento del cual tenemos ejemplares recuperados arqueológicamente desde el período Neolítico y que hacia fines del Predinástico y durante el Dinástico Temprano habrían tenido cierta relevancia política y ritual, evidente en su colocación en recintos mortuorios y cultuales de la realeza. ${ }^{11}$

Lo que merece ser tenido en cuenta es que los contextos en los que aparece esta clase de evidencia iconográfica y arqueológica de mutilaciones (se las entienda como ejecuciones o como decapitaciones -y eventuales castraciones- postmortem) corresponde a las fases Nagada IIb-IIIb y comienzos del período Dinástico Temprano, esto es, a unos contextos históricos estatales (primero atestiguados en el Alto Egipto, posteriormente a lo largo del valle y el delta del Nilo) en los que la diferencia o el límite entre lo que podría considerarse como acciones posbélicas sobre enemigos vencidos o como medidas punitivas sobre población subordinada se difumina. Alejándonos brevemente del ámbito estricto de la egiptología, una breve reflexión del antropólogo David Graeber en relación con poblaciones nilóticas de lo que es hoy Sudán del Sur aclarará el sentido de esta observación.

En palabras del investigador, los viajeros europeos que dejaron testimonio de sus experiencias entre algunas de dichas poblaciones durante el siglo XIX descubrieron que "cuando los reyes nilóticos les pidieron que condujeran raides o lanzaran disparos aleatorios sobre 'aldeas enemigas', éstas resultaron estar en verdad "habitadas por los mismos súbditos del rey", circunstancia que lleva al autor a concluir que en situaciones de dominación política de este tipo "no hay una diferencia fundamental en la relación entre un soberano y su pueblo [léase, sus súbditos o las aldeas sometidas a su dominio territorial], y entre un soberano

11 Aunque también pudieron tener otras funciones asociadas con actividades económicas o rituales que involucraran a animales no humanos, los cuchillos o puñales son a menudo considerados como parte del armamento orientado a la actividad militar de los períodos Predinástico y Dinástico Temprano (Wolf, 1926: 9-12; Gilbert, 2004: 41-43, 70). Su portación por parte de personajes en actitud de combate en la iconografía del mango de cuchillo de Dyebel el-Arak (Nagada IIcd) contribuye a esta clase de lectura. Pero tal como sugieren autores como Needler (1956: 43) o Gilbert (2004: 42-43), los cuchillos pueden ser también asociados a escenas de presuntos sacrificios, ejecuciones o mutilaciones humanos. Aparte de la asociación con la decapitación que venimos de proponer, dos etiquetas de madera de los reinados de Aha y Dyer de la Dinastía I contienen la escena de un personaje arrodillado, al parecer dirigiendo o clavando un objeto, en ocasiones identificado con un cuchillo o puñal, en el pecho de otro personaje, también arrodillado pero con los brazos aparentemente atados a la espalda (Wilkinson, 1999: 266-267; Crubézy y Midant-Reynes, 2005: 65-66; Morris, 2007: 20-21). El motivo de la etiqueta de Aha ha sido, en rigor, parcialmente "reconstruido" a partir de dos fragmentos hallados en el complejo mortuorio de dicho rey en Abidos. La escena del supuesto sacrificio (pues así se la ha, en ocasiones, interpretado) permanece, no obstante, íntegra. Véase Petrie (1901: pls. 3.4, 3.6); Vandier (1952: 835); Morris (2007: 20). Otros autores, como Bestock (2018: 218, n. 4), cobijan dudas sobre la interpretación que puede hacerse de tales etiquetas. 
y sus enemigos. Dentro y fuera están ambas constituidas a través de -como mínimo- la posibilidad de la violencia indiscriminada" (Graeber, 2011: 55). ${ }^{12}$

Consideremos ahora tres testimonios que abonarán el terreno para una reflexión similar para el valle del Nilo de los períodos de emergencia, expansión y consolidación de lo estatal. El primero de ellos es la Cabeza de Maza de Escorpión, hallada en el depósito principal de Hieracómpolis y datada hacia Nagada IIIb (Baines, 1996: 367-368). Este artefacto que, por su forma de arma de guerra, probablemente evoque la fuerza física asociada con la actividad militar o con el atributo guerrero del rey, presenta en el registro superior a una serie de estandartes que sostienen colgadas, más exactamente ahorcadas, a unas aves-rejit, al tiempo que, en un sector dañado, se alcanza a apreciar una continuidad de la escena en la que los elementos que permanecen colgados son $\operatorname{arcos}^{13} \mathrm{Tal}$ motivo que acompaña a las otras escenas -al parecer rituales- que tienen por protagonista al rey, compone lo que parece ser una declaración sobre la dominación o sobre la acción violenta sobre poblaciones enemigas (arcos que podrían remitir a la futura imagen de los Nueve Arcos como los enemigos del rey de las Dos Tierras) y, simultáneamente (o, mejor dicho, con igual valoración), sobre poblaciones subordinadas (aves-rejit) (Baines, 1996: 367-368). Tratándose de un documento de la fase conocida como "unificación", esto es, de los años en los que habría tenido lugar un proceso de expansión política que dio forma o constituyó al Estado dinástico, no puede soslayarse la similitud que debió haber existido entre, por un lado, la actividad o imposición militar y, por el otro, el uso o la amenaza de la fuerza para sostener una dominación política (por ejemplo, para la captura de tributo), lo cual hace que diferenciar entre una y otra sea sólo una cuestión de perspectiva o, a lo sumo, de temporalidad en la reproducción de una relación mediada en última instancia por la fuerza entre las entidades políticas en juego.

El otro testimonio que apunta en la misma dirección sirve más bien para apuntalar la lectura recién expuesta, pues corresponde a un período posterior, más concretamente a la Dinastía III. Se trata de la base de una estatua del rey Djoser en la cual no sólo son representados los Nueve Arcos bajo los pies del rey, sino también tres aves-rejit inmediatamente delante de ellos, como si ambos grupos estuvieran sometidos a alguna forma de dominación, por mucho que los primeros -acaso por conceptualizar la "posible resistencia al orden, al rey" (O'Connor y Quirke, 2003: 12)- estén siendo pisoteados y las segundas -acaso población sometida sin capacidad inmediata para rebelarse- reposan simplemente a sus pies (Baines, 1996: 368; Campagno, 2013: 215).

Finalmente, en Nag el-Hamdulab, en la zona de Asuán al oeste del Nilo, se han documentado -tal como vimos más arriba- unos grabados rupestres datados hacia Nagada IIIb (Hendrickx, Darnell y Gatto, 2012). Estos no sólo contienen

12 Traducción propia. Los testimonios que emplea Graeber (2011: 12) son recuperados de un relevamiento hecho por Simonse (1992: 193-195).

13 La asociación entre estandartes y prisioneros o personajes que parecen estar a punto de ser ejecutados es evidente también en objetos como las paletas de los Toros y del Campo de Batalla o en artefactos del reinado de Narmer. 
escenas asociadas a rituales regios en cuyo centro aparecen embarcaciones $y$, al menos en una de ellas, lo que parece ser la conmemoración de algún tipo de victoria militar o situación de dominación, sino que incluyen una inscripción jeroglífica que ha sido traducida como "seguimiento náutico" ( $\check{s} m s w)$, entendido como una forma temprana del ritual de "seguir a Horus" que vincularía la celebración territorial de la realeza con la recolección de tributos o el recuento de recursos (Hendrickx, Darnell y Gatto, 2012: 1080-1081 y fig. 11; Darnell, 2015). ${ }^{14}$ Una pregunta que surge aquí es: ¿se trata de la conmemoración de un combate, de una incursión militar, de una razzia, de un viaje con respaldo armado para capturar recursos de un territorio considerado propio? Pero igualmente cabe el interrogante: ¿cuál sería realmente la diferencia entre cualquiera de estos escenarios en un período de expansión política como el que corresponde a esta fase de la historia del valle del Nilo? Esta forma de expresión de la "dominación regia sobre los humanos potencialmente caóticos" (Hendrickx, Darnell y Gatto, 2012: 1081), compuesta de violencia, ritualidad regia, transporte fluvial y obtención de recursos, no haría sino desdibujar, nuevamente, los límites entre las dimensiones externa e interna de la coerción estatal en un período de expansión política y consolidación de la realeza. Y recordaría que la relación entre el Estado dinástico una vez constituido y sus súbditos estaría igualmente atravesada por la posibilidad, y a menudo probablemente la realidad, de la violencia (Graeber, 2011: 55). ${ }^{15}$

\section{Reflexiones finales}

Podemos hacer nuestro el cuestionamiento de Abraham Rosenvasser a la idea de una aversión a la crueldad inherente a las poblaciones del antiguo Egipto de la época dinástica, ${ }^{16}$ y extenderlo a las fases de emergencia, expansión y consolidación de lo estatal. Si, como sugiere el autor en su ejercicio de comparación histórica, las prácticas e imágenes del tipo que nos convoca son hechos "de naturaleza estrictamente institucional" (Rosenvasser, 1961: 116), se concibe que el rey hace (física o iconográficamente) lo que dicta el deber ser de la realeza, acaso conceptualizado como una prescripción de las divinidades (la conexión divina más allá de la figura misma del rey-dios sería más clara en períodos posteriores, algunas de cuyas inscripciones epigráficas e iconográficas visibilizan la "dedicación" de un triunfo a determinadas entidades divinas). Como afirma Bestock (2018: 265), si bien concentrándose en las imágenes antes que en las presuntas prácticas, el motivo del rey ritualmente violento o de las consecuencias de tal rol (léase, la captura, la real o potencial ejecución

14 De hecho, tal inscripción se completaría con la forma $n h b$ b3 que ha sido traducida como "tributación de la localidad-piel-de-pantera" (Darnell, 2015: 29). Para una lectura distinta de la inscripción jeroglífica de Nag el-Hamdulab, véase Begon (2016), quien sin embargo reconoce, en un personaje sosteniendo lo que parece ser un cuenco sobre su cabeza, una práctica de tributación.

15 Sobre la capacidad de coerción del Estado egipcio durante estas épocas, véase Trigger (1993: 69-71); Campagno (2013: 214-215).

16 Sobre la violencia en el antiguo Egipto, véanse las reflexiones de Sales (2018). 
y/o la mutilación de enemigos vencidos o población sometida) moviliza una obligación regia que no depende tanto de la personalidad del individuo como de su condición como "encarnación de una institución". Dicho de otro modo, se trata de prácticas que responden a la dimensión constitutivamente coercitiva del Estado. Este último se vale de las mismas herramientas para la guerra y para la coerción "interna" (y para las fases finales o resolutivas de ambas), probablemente porque no hiciera mayor diferencia entre un tipo de población y la otra (aun cuando elaborara distinciones discursivas o tipificaciones geográficas o étnicas que pudieran hacerse más elocuentes a lo largo de la historia faraónica). Si acaso puede reconocerse una diferencia (no deja de configurarse una delimitación ideológica entre las Dos Tierras y sus periferias), ésta estaría supeditada a los límites impuestos por la geografía y la logística a la posibilidad de una dominación regular. ${ }^{17}$ Tales límites serían básicamente coincidentes, a partir de comienzos de la Dinastía I, con los obstáculos impuestos a la navegación por la primera catarata en el sur y la costa del mar Mediterráneo en el norte (Wengrow, 2007 [2006]: 181), sumados a la delimitación supuesta por los desiertos circundantes, franqueados sólo en algunos puntos como oasis o mediante vías como wadis. ${ }^{18}$

Con anterioridad a la emergencia de lo estatal, o contemporáneamente a ella en comunidades no absorbidas o capturadas por un aparato de dominación, la violencia también parece haber ocupado un lugar de importancia sociopolítica (Gayubas, 2014). Los personajes destacados que son representados en vasos cerámicos de fines de Nagada I, presuntos líderes en un contexto caracterizado por la existencia de sociedades de jefatura, pudieron deber su

17 Tal como observa el historiador militar John Keegan (2014 [1993]: 95), dos clases de factores confluyen en todo proceder político asentado en el uso de la fuerza: aquellos de carácter permanente (por ejemplo, el terreno o la geografía) y aquellos contingentes (por ejemplo, las capacidades de abastecimiento, equipamiento y movilidad). Esto puede pensarse tanto para procesos de expansión político-militar como para el sostenimiento de una dominación estable basada en la coerción o su amenaza.

18 Este proceso fue en ocasiones vinculado a una identificación ya sea étnica o religiosa relativa al espacio del Alto y el Bajo Egipto que precedería y explicaría el límite a la expansión y la conformación de los límites del Estado dinástico. De acuerdo con Wengrow (2007 [2006]: 50), el impacto social del empleo de embarcaciones con remos que, vinculado a la economía agrícola-ganadera, debió incidir en los ritmos de vida, creencias y otros aspectos de las sociedades del valle del Nilo a partir de fines de Nagada I y comienzos de Nagada II, debió hallar su límite meridional en la primera catarata, configurándose una disparidad "cultural" que gradualmente diferenciaría a las poblaciones que habitaban entre la primera catarata y la costa mediterránea de otros grupos humanos que habitarían, por ejemplo, la Baja Nubia. De este modo, si hubo una identificación ideológica y social o una cierta homogeneidad de pautas culturales (aunque no, hasta donde podemos inferir, una completa uniformidad cultural o étnica) que antecedió a la delimitación política del Estado dinástico, ella parece haberse debido, en todo caso, a las mismas limitaciones topográficas que condicionaron la posterior expansión política y militar que, a su vez, cimentó la simbolización de las Dos Tierras como la "totalidad del mundo" por oposición a las regiones habitadas por las (así concebidas) "peligrosas fuerzas que amenazan a la sociedad" (Wengrow, 2007 [2006]: 258-259), no necesariamente más peligrosas que las fuerzas de lo caótico que podían habitar en el Alto o el Bajo Egipto. 
liderazgo a la actividad bélica o a cierta relación entre el ámbito militar y otras esferas de acción, y, por su propia condición como jefes, pudieron estar habilitados para disponer de prisioneros capturados en incursiones (Gayubas, 2016) y eventualmente para ejecutarlos, fuera en un contexto militar o ritual. El ejercicio de la violencia hacia afuera (en la guerra o mediante la captura o ejecución de enemigos) pudo ser por lo tanto solidario con el sostenimiento, por un lado, de la autonomía y de cierta cohesión interna, mediante la materialización de un antagonismo con las entidades políticas enemigas (Clastres, 1996 [1980]: 181-216), y por el otro, del rol del jefe como figura prestigiosa, como coordinador de esfuerzos bélicos colectivos e incluso de alianzas defensivas o como responsable práctico o simbólico de unos desempeños militares exitosos (Gayubas, 2016).

Así como el Estado se pudo valer de un repertorio preexistente de prácticas asociadas a la guerra y su resolución, si bien orientadas a otros fines, organizadas con arreglo a otros criterios, complementadas con otras formas de violencia y, sobre todo, insertas en una lógica expansiva que debió involucrar además su empleo para ejercer la dominación sostenida sobre población devenida subordinada, la expresión simbólica de tal dinámica estatal debió suponer también el recurso a un repertorio visual preexistente, reconfigurado, resignificado $\mathrm{y}$, en algunas de sus manifestaciones (como el motivo del sometimiento del enemigo), formalizado (Davis, 1992: 128; Wilkinson, 1999: 31; Hendrickx y Eyckerman, 2012: 32-33). Apropiación estatal de recursos gráficos y conceptuales presumiblemente vinculados, en contextos preestatales, con la exaltación de figuras de liderazgo de un modo u otro relacionadas con el ámbito bélico, que no debe opacar la diferencia en el paradigma semántico (Colombo, 1999) de cada escenario.

Una observación de David Wengrow relativa al empleo de paletas cosméticas como artefacto ritual hacia fines del período Predinástico puede resultar de interés aquí. Como plantea el autor, estos objetos votivos que son, a su vez, soportes para inscripciones iconográficas y textuales del Estado, hunden su significación en (o, en el enfoque del investigador, marcan una continuidad con) la utilidad o uso ancestral de tal clase de objetos. Así, la elección de las paletas cosméticas como vehículo ideológico, lejos de ser casual, se inscribe en una tradición del cuidado del cuerpo que puede rastrearse hasta el período Neolítico y evoca, de este modo, una pauta de vida social y ritual en cuyo centro se sitúa el cuerpo (Wengrow, 2007 [2006]: 59-63, 256-260). En un mismo sentido, aunque el autor no se detiene en ello, las cabezas de maza y los mangos de cuchillo empleados como soporte de las conmemoraciones regias de fines de Nagada II y, especialmente, de Nagada IIIab y comienzos de la Dinastía I, parecen hallar su sentido o valor simbólico en el uso tradicionalmente dado a dichos objetos desde el período Neolítico en adelante, esto es, como armas de guerra y ejecución. Si, en cierto modo, el empleo de la paleta cosmética como vehículo de expresión de la realeza conmemora la centralidad del cuerpo político y cósmico del rey (cuyo cuerpo muerto, por otro lado, debe ser cuidado y conservado tal como fuera mantenida ritualmente su juventud en vida), la elección de armas de guerra o ejecución asociadas, por lo menos en el caso de la maza, a la expresión de prestigio o liderazgo desde al menos Nagada Ic pero no por eso desvestidas de su connotación 
bélica, sugiere fuertemente un movimiento de apropiación simbólica de la función militar, coincidente con el fenómeno de concentración estatal de la capacidad militar. ${ }^{19}$

La cuestión del cuerpo merece una última reflexión. Acaso puede aventurarse, siguiendo a Davis (1992: 99), que el cuerpo representado es menos un cuerpo físico que un cuerpo social, político. Pero también lo sería el cuerpo ritualizado en una presumible performance física: tanto el rey, en tanto "encarnación de una institución" (Bestock, 2018: 265), como el enemigo derrotado, sea un jefe ("cabeza" de Estado o jefatura) o bien uno o más exponentes intercambiables según un criterio de sustitución social (Kelly, 2000: 5), encarnación de la población periférica vencida o del grupo social sometido. ${ }^{20}$ Este principio, que podría parecer en exceso filosófico, no lo es tanto si atendemos a una peculiar forma de representación que es documentada a comienzos y a finales del período Dinástico Temprano. En una etiqueta del reinado de Narmer, un presunto enemigo vencido a punto de ser ejecutado por el rey en forma de pez siluro tiene en su cabeza unas plantas de papiro que parecen identificarlo con el delta del Nilo (Wengrow, 2007 [2006]: 246). Esta conexión entre un cuerpo individual y un elemento del paisaje no parece tener otra función que la identificación de un referente humano (equivalente o jerárquico) con un lugar habitado y, en definitiva, la simbolización de un colectivo social en su relación con un espacio o territorio. Más elocuente aún es la variante presente en la Paleta de Narmer, en la cual la cabeza de un enemigo sobresale de una especie de plataforma que recuerda el signo jeroglífico $t 3$ ("tierra"), por encima de la cual emergen nuevamente las plantas de papiro. En lo que concierne a finales de la Dinastía II, individuos derrotados con plantas de papiro en la cabeza son representados en una base de estatua y en una serie de vasos de piedra del reinado de Jasejem/ uy. Significativamente, en este período también se documenta el sometimiento de un enemigo nubio, identificado como tal por llevar en la cabeza un arco, pero cuyo cuerpo, sin que podamos ser precisos por tratarse de un fragmento, parece consistir en una plataforma similar a la que contiene la Paleta de Narmer (Wilkinson, 1999: 178), acaso reforzando la conexión entre un cuerpo individual, un colectivo social y un espacio o territorio.

Para concluir, ¿qué nos dice la mutilación, más concretamente la decapitación, en relación con esta cuestión? Como reflexiona Francisco Gracia Alonso en un estudio histórico comparativo, la separación de la cabeza del cuerpo puede tener un valor tanto físico como metafórico y formar parte de unos presupuestos ideológicos asociados con el ejercicio del poder (Gracia Alonso, 2017: xi-xiii). Ciertamente, la crueldad y las vejaciones son efectivos instrumentos de guerra y dominación que actúan a nivel físico y psicológico y permiten fijar el recuerdo de una agresión o una victoria/derrota - para las poblaciones vencedora y vencida, respectivamente- (Gracia Alonso, 2017: 28). Pero el precepto ideológico

19 En este último caso, el cuerpo afectado es el de quien recibe -siquiera simbólica o potencialmente- la violencia.

20 Si tal acción involucrara a más figuras, por ejemplo funcionarios ejecutando, del modo que fuera, aquello que en la iconografía realiza el rey, acaso la delegación práctica de la violencia no estaría negando la implicancia simbólica del acto. 
que pudo estar operativo en el valle del Nilo de fines del período Predinástico y comienzos del Dinástico Temprano pudo añadir una dimensión simbólica a tal práctica que justificara su representación.

Por un lado, esta clase de "necroviolencia" (Morris, 2018: 133) -si concebimos la posibilidad de que fuera ejecutada post-mortem, pero incluso si la contemplamos como una forma de ejecución, dado el efecto generado sobre la materialidad del cuerpo- pudo suponer una forma de destrucción física e inhabilitación ideológica del vencido sobrepasando la barrera que separa la vida de la muerte, en una sociedad que concibe ambas esferas como estados de la existencia. La castración representada en la Paleta de Narmer acaso pudo simbolizar la pérdida de potencia del enemigo vencido y la deseada imposibilidad de su reproducción sea como grupo social o como individuos en el más allá -sin que pueda descartarse, no obstante, un método de contabilización como el que se documentaría en otros períodos de la historia faraónica. Respecto a la decapitación, quizás ejecutara o simbolizara la muerte de la persona, su imposibilidad de existencia después de la muerte del cuerpo físico o, como mínimo, la dificultad puesta a ello a raíz de la obstaculización de un enterramiento apropiado (Dougherty y Friedman, 2008: 331). Tal escenario sería factible ya sea que involucrara a enemigos o a población subordinada, y en lo que a la evidencia disponible respecta, tanto en relación con los indicadores osteológicos del cementerio HK43 de Hieracómpolis de la fase Nagada IIbc como con los testimonios iconográficos de fines del Predinástico y comienzos de la Dinastía I y con la referencia epigráfica contenida en la Piedra de Palermo relativa a la Dinastía I. En definitiva, como observa Picardo (2004: 13-14) tras un repaso diacrónico de representaciones textuales y visuales de la historia faraónica, si bien "sólo enemigos no egipcios en tiempos de guerra merecían la decapitación", la "literatura funeraria indica que la decapitación después de la muerte era un castigo [no sólo] para los enemigos de los dioses", sino también para los "difuntos egipcios juzgados no aptos para entrar en la compañía de los dioses", en la medida en que éstos "devenían efectivamente enemigos y podían ser tratados en consecuencia". Puede por lo tanto concluirse que la decapitación era "infligida como castigo a quienes se opusieran al rey, y al orden" (Dougherty y Friedman, 2008: 330), fueran conceptualizados como habitantes de regiones periféricas o como súbditos dentro del territorio reconocido como propio, circunstancia que puede pensarse para las épocas que aquí nos conciernen.

Por otro lado, tal clase de agresión y su representación pudieron tener un valor no sólo individual o personal sino colectivo. Según lo que hemos considerado en relación con el cuerpo físico y representado, la mutilación pudo implicar no solamente a los individuos sino a los grupos sociales a los que tales figuras identificaban, fuera en calidad de personalidades destacadas (jefes, líderes u otros) o de equivalentes. Cualquiera fuera la cantidad de individuos que, vencidos en una situación de violencia bélica o de coacción sobre un territorio previamente dominado, sufrieran la decapitación, la representación de unas pocas hileras de personajes decapitados en los artefactos de fines del período Predinástico y comienzos de la Dinastía I indica que esta imagen (o su posible referente físico) pudo bastar para simbolizar el descabezamiento de un grupo considerado hostil. Baste recordar que el signo jeroglífico tp, que consiste en una cabeza de perfil, se traduce en ocasiones como "jefe" o como la instancia 
superior o directriz de una entidad o relación. Así, si en contextos no estatales podemos suponer que se vencía militarmente en episodios de ataque y retirada en los que pudieron capturarse o ejecutarse prisioneros pero manteniendo cierto statu quo que implicaría la reproducción intermitente de ciclos de violencia entre comunidades o entidades políticas de jefatura, en contextos de estatalidad la victoria debía conducir a desarmar y descabezar al enemigo o rebelde, en el mejor de los casos convirtiéndolo en -o devolviéndolo a la condición desúbdito. La decapitación como práctica o representación pudo ser un efectivo mensaje de tal principio de dominación, esto es, de la concentración estatal de la violencia. 
"Baines, J. (1995). Origins of Egyptian Kingship, en: O’Connor, D. y Silverman, D. P. (eds.), Ancient Egyptian kingship. Leiden: Brill, 95-156.

»Baines, J. (1996). Contextualizing Egyptian Representations of Society and Ethnicity, en: Cooper, J. S. y Schwartz, G. (eds.), The Study of the Ancient Near East in the 21st Century: The William Foxwell Albright Centennial Conference. Winona Lake: Eisenbrauns, 339-384.

»Bárta, M. y Frouz, M. (2010). Swimmers in the Sand. On the Neolithic Origins of Ancient Egyptian Mythology and Symbolism. Praga: Dryada.

"Begon, M. (2016). Aux origines de l'exploitation pharaonique des carrières d'Assouan? Retour sur la lecture de l'inscription du bas-relief de Nag elHamdulab (NH 7, tableau 7a), en: Archéo-Nil 26: 173-183.

»Bénédite, G. (1916). Le couteau de Gebel el-Arak, étude sur un nouvel objet préhistorique acquis par le Musée du Louvre, en: Monuments et mémoires de la Fondation Eugène Piot 22 (1): 1-34.

»Bestock, L. (2018). Violence and Power in Ancient Egypt: Image and Ideology before the New Kingdom. Londres-Nueva York: Routledge.

"Campagno, M. (2002). De los jefes-parientes a los reyes-dioses. Surgimiento y consolidación del Estado en el antiguo Egipto, del Período Badariense al Dinástico Temprano, ca. 4500-2700 a.C. Barcelona: Aula Ægyptiaca.

»Campagno, M. (2004). In the Beginning Was the War. Conflict and the Emergence of the Egyptian State, en: Hendrickx, S., Friedman, R. F., Ciałowicz, K. M. y Chłodnicki, M. (eds.), Egypt at Its Origins. Studies in Memory of Barbara Adams. Proceedings of the International Conference "Origin of the State. Predynastic and Early Dynastic Egypt", Krakow, 28th August - 1st September 2002. Lovaina: Peeters, 689-703.

"Campagno, M. (2013). Coercion, Creation, Intervention: Three Capacities of the Early Egyptian State, en: Frood, E. y McDonald, A. (eds.), Decorum and experience. Essays in ancient culture for John Baines. Oxford: Griffith Institute, 214-219.

»Campagno, M. (2016). Surgimiento de lo estatal y liderazgo local en el valle del Nilo (IV-III milenios a.C.), en: Campagno, M., Gallego, J. y García Mac Gaw, C. G. (comps.), Regímenes políticos en el Mediterráneo Antiguo. Buenos Aires: Miño y Dávila, 15-29.

"Campagno, M. y Gayubas, A. (2015). La guerra en los comienzos del antiguo Egipto: reflexiones a partir de la obra de Pierre Clastres, en: Cuadernos de Marte. Revista latinoamericana de sociología de la guerra 8: 11-46.

» Capart, J. (1905). Primitive Art in Egypt. Londres: H. Grevel \& Co.

"Capart, J. (1940). Avant-propos, en: Posener, G., Princes et pays d'Asie et de Nubie. Textes hiératiques sur des figurines d'envoutement du Moyen Empire. Bruselas: Fondation Égyptologique Reine Élisabeth, 5-9.

"Carneiro, R. L. (2012). The Circumscription Theory: AClarification, Amplification, and Reformulation, en: Social Evolution \& History 11 (2): 5-30. 
»Cervelló Autuori, J. (2009). La aparición del Estado y la época Tinita, en: Parra Ortiz, J. M. (coord.), El antiguo Egipto. Sociedad, economía, política. Madrid: Marcial Pons, 69-124.

»Ciałowicz, K. M. (1987). Les têtes de massues des périodes prédynastique et archaïque dans la vallée du Nil. Varsovia-Cracovia: Uniwersytet Jagielloński Panstwowe Wydawnictwo Naukowe.

"Ciałowicz, K. (2011). The Predynastic/Early Dynastic Period at Tell el-Farkha, en: Teeter, E. (ed.), Before the Pyramids. The Origins of Egyptian Civilization. Chicago: The Oriental Institute of the University of Chicago, 55-64.

»Clastres, P. (1996 [1980]). Investigaciones en antropología política. Barcelona: Gedisa.

»Colombo, E. (1999). El Estado como paradigma de poder, en: Ferrer, C. (comp.), El lenguaje libertario. Antología del pensamiento anarquista contemporáneo. Buenos Aires: Altamira, 53-74.

»Crubézy, E. y Midant-Reynes, B. (eds.) (2005). Les sacrifices humains à l'époque prédynastique. L'apport de la nécropole d'Adaïma, en: Albert, J-P. y MidantReynes, B. (eds.), Le sacrifice humain en Égypte ancienne et ailleurs. París: Soleb, 58-81.

"Darnell, J. C. (2002). Theban Desert Road Survey in the Egyptian Western Desert, Vol. 1: Gebel Tjauti Rock Inscriptions 1-45 and Wadi el-Hôl Rock Inscriptions 1-45. Chicago: The University of Chicago Press.

»Darnell, J. C. (2015). The Early Hieroglyphic Annotation in the Nag el-Hamdulab Rock Art Tableaux, and the Following of Horus in the Northwest Hinterland of Aswan, en: Archéo-Nil 25: 19-43.

"Davis, W. (1992). Masking the Blow. The Scene of Representation in Late Prehistoric Egyptian Art. Berkeley-Los Angeles-Oxford: University of California Press.

»De Wit, T. J. (2008). Enemies of the State: Perceptions of 'otherness' and state formation in Egypt. MA Thesis, Leiden University.

»Diego Espinel. A. (2006). Etnicidad y territorio en el Egipto del Reino Antiguo. Bellaterra: Universitat Autònoma de Barcelona.

»Dougherty, S. P. y Friedman, R. (2008). Sacred or Mundane: Scalping and Decapitation at Predynastic Hierakonpolis, en: Midant-Reynes, B. y Tristant, Y. (eds.), Egypt at Its Origins 2. Proceedings of the International Conference "Origin of the State. Predynastic and Early Dynastic Egypt", Toulouse, 5-8th September 2005. Lovaina: Peeters, 311-338.

»Dreyer, G., Hartung, U. y Punpenmeier, F. (1993). Umm el-Qaab. Nachuntersuchungen im frühzeitlichen Königsfriedhof. 5./6. Vorbericht, en: Mitteilungen des Deutschen Archäologischen Instituts abteilung Kairo 49: 23-62.

» Dreyer, G., Hartung, U., Hikade, T., Köhler, E. C., Müller, V. y Pumpenmeier, F. (1998). Umm el-Qaab. Nachuntersuchungen im frühzeitlichen Königsfriedhof. 9./10. Vorbericht, en: Mitteilungen des Deutschen Archäologischen Instituts abteilung Kairo 54: 77-167.

" Dreyer, G., Hartmann, R., Hartung, U., Hikade, T., Köpp, H., Lacher, C., Müller, V., Nerlich, A. y Zink, A. (2003). Umm el-Qaab. Nachuntersuchungen im frühzeitlichen Königsfriedhof. 13./14./15. Vorbericht, en: Mitteilungen des Deutschen Archäologischen Instituts Abteilung Kairo 59: 67-138.

»Droux, X. (2005). Une représentation de prisonniers décapités en provenance 
de Hiérakonpolis, en: Bulletin de la Société d'Egyptologie de Genève 27: 33-42.

"Droux, X. (2007). Headless at Hierakonpolis, en: Nekhen News 19: 14.

»Emery, W. B. (1961). Archaic Egypt. Harmondsworth: Penguin Books.

"Ferguson, R. B. (1997). Violence and War in Prehistory, en: Martin, D. L. y Frayer, D. W. (eds.), Troubled Times. Violence and Warfare in the Past. Amsterdam: Gordon and Breach Publishers, 321-355.

» Friedman, R. (2011). Hierakonpolis, en: Teeter, E. (ed.), Before the Pyramids. The Origins of Egyptian Civilization. Chicago, The Oriental Institute of the University of Chicago, 33-44.

»Gayubas, A. (2014). Pierre Clastres y la guerra en el valle del Nilo preestatal, en: Campagno, M. (ed.), Pierre Clastres y las sociedades antiguas. Buenos Aires: Miño y Dávila, 143-162.

»Gayubas, A. (2015). Warfare and Social Change in Non-State Societies of the Predynastic Nile Valley, en: Aula Orientalis. Revista de estudios del Próximo Oriente Antiguo 33 (1): 43-49.

"Gayubas, A. (2016). Guerra, territorio y cambio social en el valle del Nilo preestatal, en: Campagno, M., Gallego, J. y García Mac Gaw, C. G. (comps.), Regímenes políticos en el Mediterráneo Antiguo. Buenos Aires: Miño y Dávila, 31-43.

"Gayubas, A. (2018). Disposiciones defensivas en el antiguo Egipto entre el período Predinástico y la Dinastía III, en: Historiae 15: 33-46.

» Gilbert, G. P. (2004). Weapons, Warriors and Warfare in Early Egypt. Oxford: Archaeopress.

"Gracia Alonso, F. (2017). Cabezas cortadas y cadáveres ultrajados. De la Prehistoria al Estado Islámico. Madrid: Desperta Ferro Ediciones.

»Graeber, D. (2011). The Divine Kingship of the Shilluk: On Violence, Utopia, and the Human Condition, or, Elements for an Archaeology of Sovereignty, en: HAU: Journal of Ethnographic Theory 1 (1): 1-62.

»Guyot, F. (2015). The Predynastic Pottery from Tell el-Iswid (Nile Delta). Preliminary Report on the Lower Egyptian Culture Assemblage, en: Bulletin de Liaison de la Céramique Égyptienne 25: 5-35.

" Hall, E. S. (1986). The Pharaoh Smites his Enemies. A Comparative Study. Múnich: Deutscher Kunstverlag.

» Hamilton, C. R. (2016). Conflict in the Iconography of the Protodynastic and Early Dynastic Periods, en: Landgráfová, R. y Mynářová, J. (eds.), Rich and Great: Studies in Honour of AnthonyJ. Spalinger on the Occasion of his 7oth Feast of Thoth. Praga: Charles University in Prague, 99-113.

» Hendrickx, S. y Eyckerman, M. (2012). Visual Representation and State Formation in Egypt, en: Archéo-Nil 22: 23-72.

»Hendrickx, S. y Huyge, D. (2014). Neolithic and Predynastic Egypt, en: Renfrew, C. y Bahn, P. (eds.), The Cambridge World Prehistory, vol. 1. Cambridge: Cambridge University Press, 240-258.

» Hendrickx, S., Darnell, J. C. y Gatto, M. C. (2012). The Earliest Representations of Royal Power in Egypt: The Rock Drawings of Nag el-Hamdulab (Aswan), en: Antiquity 86 (334): 1068-1083. 
» Herold, A. (2009). Aspekte ägyptischer Waffentechnologie - von der Frühzeit bis zum Ende des Neuen Reiches, en: Gundlach, R.y Vogel, C. (eds.), Militärgeschichte des pharaonischen Ägypten. Altägypten und seine Nachbarkulturen im Spiegel aktueller Forschung. Paderborn-Múnich-Viena-Zúrich: Ferdinand Schöningh, 187-216.

"Hierakonpolis Expedition. (s/f). HK6: the Elite Predynastic and Early Dynastic cemetery, en: Hierakonpolis-online, http://www.hierakonpolis-online.org/index. php/explore-the-predynastic-cemeteries/hk6-elite-cemetery, consultado el 184-2020.

» Hoffman, M. A. (1979). Egypt before the Pharaohs. Nueva York: Barnes \& Noble.

» Keegan, J. (2014 [1993]). Historia de la guerra. Madrid: Turner.

» Kelly, R. C. (2000). Warless Societies and the Origin of War. Ann Arbor: University of Michigan Press.

»Köhler, E. C. (2002). History or Ideology? New Reflections on the Narmer Palette and the Nature of Foreign Relations in Pre- and Early Dynastic Egypt, en: van den Brink, E. C. M. y Levy, T. E. (eds.), Egypt and the Levant. Interrelations from

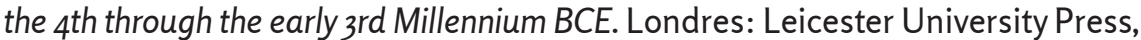
499-513.

"Ludes, B. y Crubézy, E. (2005). Le sacrifice humain en contexte funéraire. Problèmes posés à l'anthropobiologie et à la médecine légale. L'exemple prédynastique, en: Albert, J.-P. y Midant-Reynes, B. (eds.), Le sacrifice humain en Égypte ancienne et ailleurs. París: Soleb, 82-95.

»Maish, A. (1999). Report on the Physical Remains from the Predynastic Cemetery at HK43, en: Journal of the American Research Center in Egypt 36: 11-14.

" Midant-Reynes, B. (2000 [1992]). The Prehistory of Egypt. From the First Egyptians to the First Pharaohs. Oxford: Blackwell Publishing.

" Moeller, N. (2016). The Archaeology of Urbanism in Ancient Egypt. From the Predynastic Period to the End of the Middle Kingdom. Nueva York: Cambridge University Press.

"Morris, E. F. (2007). Sacrifice for the State: First Dynasty Royal Funerals and the Rites at Macramallah's Rectangle, en: Laneri, N. (ed.), Performing Death. Social Analyses of Funerary Traditions in the Ancient Near East and Mediterranean. Chicago-Illinois: The Oriental Institute of the University of Chicago, 15-37.

" Morris, E. (2018). Ancient Egyptian Imperialism. Hoboken (NJ): Wiley-Blackwell.

»Müller, V. (2008). Nilpferdjagd und geköpfte Feinde - zu zwei Ikonen des Feindvernichtungsrituals, en: Engel, E.-M., Müller, V. y Hartung, U. (eds.), Zeichen aus dem Sand. Streiflichter aus Ägyptens Geschichte zu Ehren von Günter Dreyer. Wiesbaden: Harrassowitz, 477-493.

» Needler, W. (1956). A Flint Knife of King Djer, en: The Journal of Egyptian Archaeology 42: 41-44.

» Nordström, H.-Å. (1972). Neolithic and A-Group Sites. Copenhague-Estocolmo: Scandinavian University Books.

"O'Connor, D. (2014). The Old Kingdom Town at Buhen. Londres: Egypt Exploration Society.

"O'Connor, D. y Quirke, S. (2003). Introduction: Mapping the Unknown in Ancient Egypt, en: O’Connor, D. y Quirke, S. (eds.), Mysterious Lands, Encounters 
with Ancient Egypt. Londres: UCL Press, 1-22.

»Petrie, W. M. F. (1900). The Royal Tombs of the First Dynasty. 1900. Part I. Londres: The Egypt Exploration Fund-Kegan Paul, Trench, Trübner \& Co.-Quaritch.

»Petrie, W. M. F. (1901). The Royal Tombs of the Earliest Dynasties. 1901. Part II. Londres: The Egypt Exploration Fund-Kegan Paul, Trench, Trübner \& Co.Quaritch.

»Petrie, W. M. F. (1920). Prehistoric Egypt. Londres: British School of Archaeology in Egypt.

» Picardo, N. S. (2004). Dealing with Decapitation Diachronically, en: Nekhen News 16: 13-14.

»Potter, W. E. y Powell, J. F. (2003). Big Headaches in the Predynastic: Cranial Trauma at HK43, en: Nekhen News 15: 26-27.

»Quibell, J. E. (1900). Hierakonpolis. Part I. Londres: Quaritch.

»Quibell, J. E. y Green, F. W. (1902). Hierakonpolis. Part II. Londres: Quaritch.

»Raffaele, F. (2003). Dynasty o, en: Bickel, S. y Loprieno, A. (eds.), Basel Egyptology Prize 1 (Aegyptiaca Helvetica 17). Basilea: Schwabe \& Co., 99-141.

»Raffaele, F. (2010). Animal Rows and Ceremonial Processions in Late Predynastic Egypt, en: Raffaele, F., Nuzzolo, M. e Incordino, I. (eds.), Recent Discoveries and Latest Researches in Egyptology. Proceedings of the First Neapolitan Congress of Egyptology. Naples, June 18th -20th 2008. Wiesbaden: Harrassowitz, 244-283.

» Rampersad, S. R. (1999). The Origin and Relationships of the Nubian A-Group. PhD Thesis, University of Toronto.

» Redmond, E. M. (1994). Tribal and Chiefly Warfare in South America. Ann Arbor: University of Michigan.

"Rizkana, I. y Seeher, J. (1987). Maadi I. The Pottery of the Predynastic Settlement. Maguncia: Philipp von Zabern.

» Rosenvasser, A. (1961). La muerte ritual del enemigo por el faraón, en: Humanidades 38: 107-118.

» Sales, J. d. C. (2018). Strike, Smite and Terrify: Reflections on Physical, Ritual and Psychological Violence in Ancient Egypt, en: Pimentel, M. C. y Rodrigues, N. S. (eds.), Violence in the Ancient and Medieval Worlds. Lovaina-París-Bristol: Peeters, 295-313.

» Schäfer, H. (1896). Neue Altertümer der "new race« aus Negadeh, en: Zeitschrift für Ägyptische Sprache und Altertumskunde 34: 158-161.

"Scharff, A. (1928). Some Prehistoric Vases in the British Museum and Remarks on Egyptian Prehistory, en: The Journal of Egyptian Archaeology 14 (3/4): 261-276.

"Shaw, I. (1991). Egyptian Warfare and Weapons. Princes Risborough: Shire Publications.

"Shaw, I. (2019). Ancient Egyptian Warfare. Tactics, Weapons and Ideology of the Pharaohs. Oxford-Filadelfia: Casemate Publishers.

" Simonse, S. (1992). Kings of Disaster: Dualism, Centralism and the Scapegoat King in the Southeastern Sudan. Leiden: Brill.

"Smith, G. E. (1910). The Archaeological Survey of Nubia. Report for 1907-1908. Vol. II: Report on the Human Remains. El Cairo: Survey Department. 
» Somaglino, C. y Tallet, P. (2014). Une campagne en Nubie sous la Ire dynastie. La scène nagadienne du Gebel Sheikh Suleiman comme prototype et modèle, en: ReHeT. Revue numérique d'Égyptologie 1: 1-46.

»Stevenson, A. (2016). The Egyptian Predynastic and State Formation, en: Journal of Archaeological Research 24: https://doi.org/10.1007/s10814-016-9094-7.

» Tallet, P. (2010). Le roi Den et les lountiou. Les Égyptiens au Sud-Sinaï sous la 1er dynastie, en: Archéo-Nil 20: 97-105.

» Tallet, P. y Laisney, D. (2012). Iry-Hor et Narmer au Sud-Sinaï (Ouadi ‘Ameyra). Un complément à la chronologie des expéditions minières égyptiennes, en: Bulletin de l'Institut Français d'Archéologie Orientale 112: 381-398.

» Testart, A. (2005). Doit-on parler de 'sacrifice' à propos des morts d'accompagnement?, en: Albert, J-P. y Midant-Reynes, B. (eds.), Le sacrifice humain en Égypte ancienne et ailleurs. París: Soleb, 34-57.

» Török, L. (2009). Between Two Worlds. The Frontier Region between Ancient Nubia and Egypt $3700 B C-A D$ 500. Leiden-Boston: Brill.

» Trigger, B. G. (1993). Early Civilizations: Ancient Egypt in Context. El Cairo: The American University in Cairo Press.

»Tutundžić, S. P. (1989). Relations between Late Predynastic Egypt and Palestine: Some Elements and Phenomena, en: Miroschedji, P. de (ed.), L'urbanisation de la Palestine à l'âge du Bronze ancient. Bilan et perspectives des recherché actuelles. Oxford: Tempvs Reparatvm, 423-432.

"Vandier, J. (1952). Manuel d'Archéologie Égyptienne. 1. Les époques de formation, vol. 1. La préhistoire; vol. 2. Les trois premières dynasties. París: Editions A. et J. Picard.

»Vercoutter, J. (1962). Preliminary Report of the Excavations at Aksha by the Franco-Argentine Archaeological Expedition, 1961 (with Notes relating to Inscriptions found at Aksha, by A. Rosenvasser), en: Kush 10: 109-117.

» Vogel, C. (2009). Das ägyptische Festungssystem bis zum Ende des Neuen Reiches, en: Gundlach, R. y Vogel, C. (eds.), Militärgeschichte des pharaonischen Ägypten. Altägypten und seine Nachbarkulturen im Spiegel aktueller Forschung. Paderborn-Múnich-Viena-Zúrich: Ferdinand Schöningh, 165-185.

»Wendorf, F. (1968). Site 117: A Nubian Final Palaeolithic Graveyard near Jebel Sahaba, Sudan, en: Wendorf, F. (ed.), The Prehistory of Nubia, vol. 2. Dallas: Southern Methodist University Press, 954-995.

»Wendorf, F. y Schild, R. (1986). The Wadi Kubbaniya Skeleton: A Late Paleolithic Burial from Southern Egypt. Dallas: Southern Methodist University Press.

"Wengrow, D. (2007 [2006]). La arqueología del Egipto arcaico. Transformaciones sociales en el noreste de África (10.000-2650 a.C.). Barcelona: Bellaterra.

»Wilkinson, T. A. H. (1999). Early Dynastic Egypt. Londres: Routledge.

»Wilkinson, T. (2000). Royal Annals of Ancient Egypt. The Palermo Stone and its Associated Fragments. Londres: Routledge.

»Williams, B. B. (1986). The A-Group Royal Cemetery at Qustul: Cemetery L. Chicago: The Oriental Institute of the University of Chicago.

"Wolf, W. (1926). Die Bewaffnung des altägyptischen Heeres. Leipzig: J. C. Hinrichs. 
